\title{
GCU
}

Glasgow Caledonian

University

University for the Common Good

\section{"We are GREAT Britain": British newspaper narratives during the London 2012 Olympic Games}

Vincent, John; Hill, John S.; Billings, Andrew; Harris, John; Massey, C. Dwayne

Published in:

International Review for the Sociology of Sport

DOI:

$10.1177 / 1012690217690345$

Publication date:

2018

Document Version

Author accepted manuscript

Link to publication in ResearchOnline

Citation for published version (Harvard):

Vincent, J, Hill, JS, Billings, A, Harris, J \& Massey, CD 2018, "'We are GREAT Britain": British newspaper narratives during the London 2012 Olympic Games', International Review for the Sociology of Sport, vol. 53, no. 8, pp. 895-923 . https://doi.org/10.1177/1012690217690345

\section{General rights}

Copyright and moral rights for the publications made accessible in the public portal are retained by the authors and/or other copyright owners and it is a condition of accessing publications that users recognise and abide by the legal requirements associated with these rights.

Take down policy

If you believe that this document breaches copyright please view our takedown policy at https://edshare.gcu.ac.uk/id/eprint/5179 for details of how to contact us. 
"We Are GREAT Britain": British Newspaper Narratives during the London 2012 Olympic Games

\begin{abstract}
British newspaper narratives were examined during the 2012 London Olympic Games to discern how the British press promoted specific 'narratives of the nation' (Hall, 2000). For the London-based British press, the home Olympics became the ideal medium not only to sell newspapers and electronic format subscriptions, but also to (re)present their views on Britain and what it stood for. Using a qualitative textual analysis methodology, this study drew on Anderson's (1983) theory of the 'imagined community' and Edmunds and Turner's (2001) concepts of benign and malign nationalism to provide insights about how Britishness was framed. For a country struggling to shake off the economic recession, early narratives about the Games were imbued with concerns about the escalating costs of hosting the Games and fears of terrorism. However, the critical early tone of British newspaper narratives was supplanted with uplifting, inspirational stories about the unprecedented success of Team GB athletes. This provided British journalists with an opportunity to reengineer Britishness to reinforce some traditional values and inject some new inclusive ones. Although at times, complex, contested and contradictory, the narratives generally linked the internationalism of the Olympics with a progressive, benign version of Britishness that emphasized inclusion, tolerance, and creativity and, at least temporarily, redefined how Britain regarded itself and was viewed.
\end{abstract}

\title{
Keywords
}

London Olympic Games, Textual Analysis, British Newspaper Narratives 
"We Are GREAT Britain": British Newspaper Narratives during the London 2012 Olympic Games "Sport has the power to change the world, to inspire, and to unite people in a way that little else can." (Nelson Mandela, 2000)

\section{Introduction}

On 6 July 2005, the International Olympic Committee (IOC) named London as the host of the XXX Olympiad, which made it the first city to host the Games three times (Llewellyn, 2012). For the 17day period of the 2012 London Olympic Games (LOG) the mass-mediated spectacle captured the British and global public imagination as its showcased each nations' best athletes. As Poulton and Maguire (2012: 12) noted, the home nation "...is at the core of the Olympic spectacle," and, as such, this study examined how selected broadsheet and popular London-based British newspapers' narratives framed British identity during the 2012 LOG. As only the lucky few received tickets through the ticket lottery to watch Olympic sports and events in person, the overwhelming majority consumed the Games through the media (Tomlinson, 2014). Most people watched it on television, or through live streams, and read about it in newspapers. For those reading newspapers, the narratives about the LOG served to construct, (re)produce, and reflect shared ideas about Britishness, when Team GB athletes become personifications of the national identity, character, and culture, and the inherent tensions between the internationalism of the Olympic ethos and nationalism unfold.

The following sections will explore the sport media, nationalism nexus in relation to the LOG, before outlining the theoretical frameworks this study draws on to help make sense of the (re)construction of Britishness in the newspaper narratives in the rarefied atmosphere of the home Olympics. Finally, we provide a socio-historical context of British national identity and an overview of the 2012 LOG.

\section{The Sport Media, Nationalism Nexus}

Globalized, commodified, celebrity sports stars feature prominently in newspaper narratives to make sporting events interesting and sell more copies. However, as Whannel (2002) noted, mediated 
sport accounts about national identity at major international sporting events still make a significant impact on national identity and culture. Indeed Rowe, et al. (1998: 133) described the interplay between mediated accounts of international sporting events as the "sport-nationalism-media troika" because as Polley (1998: 35) commented, "a national team can, in media and popular discourse, take on the guise of the nation itself." Thus, newspaper narratives have considerable influence in communicating national identity through the prism of mega sporting events like the Olympic Games. Media play a major role in constructing, (re)producing and reinforcing narratives and images, which communicate shared meanings, understandings, and values about national identity (Billings, 2008).

The potential of the Olympic Games to induce a spirit of internationalism consistent with the intent of founder Baron de Coubertain and the Olympic Charter has been frequently undermined because as Butterworth (2007: 187) noted that the Olympic Games have been “... a forum for fervent nationalism" rather than "... peaceful competition." As an illustration, Billings et al. (2011) stated that a major goal of the Chinese during the 2008 Beijing Olympic Games was to finish first in the medal table to demonstrate its emergence as a superpower. In a longitudinal study Billings (2008) concluded that in a drive for ratings to maximize advertising rates NBC's televised coverage of the Olympic Games between the 1996 Summer and the 2006 Winter Olympics were imbued with a strong home nation bias, with United States athletes receiving a disproportionately high amount of coverage with 44 of the 60 most mentioned athletes representing the United States. With feelings of national identity heightened during the Olympics, Vincent and Crossman (2015) noted nationalism is a feature of print and electronic media coverage across most countries including Switzerland and Italy (Chen and Colapinto, 2010), Canada and New Zealand, (Knight, et al., 2005), China and the United States, (Gao, 2010), Australia, Great Britain, and the United States (Larson and Rivenburgh, 1991), with the only issue being the degree of national bias and how national identity politics manifests itself (Billings et al., 2011). 


\section{Theoretical Framework(s): The Social Construction of National Identity}

Cultural studies scholars like Bhabha (1990) and Hall (2000) viewed national identity as a

product of narratives constructed and disseminated in national histories, literature, and popular culture.

Hall (2000: 613) described how a sense of national consciousness and belonging is socially constructed, thus:

National cultures construct identities by producing meanings about "the nation" with which we can identify; these are contained in the stories which are told about it, memories which connect its present with its past, and memories which are constructed of it.

Drawing on the notion that national identity is a cognitive construct, Benedict Anderson (1983) famously described the nation as an 'imagined community.' Anderson (1983: 6) posited that a sense of national identity and community is created in people's minds or imaginations which they believe is shared with other citizens "... because the members of even the smallest nations will never know most of their fellow-members, meet them, or even hear of them, yet in the minds of each lives the image of their communion." This sense of connectedness among citizens can be generated through newspaper narratives, each consumed simultaneously by fellow citizens, which strengthens their shared sense of belonging and allegiance to an extended family - the nation. Miller (1995: 32) paraphrased the concept of 'imagined community' thusly:

How do I know what it means to be British? I find out from newspaper editorials, or history books, or film or songs - and I take for granted that what I am ingesting is also being ingested by millions of other Britons whom I will never meet.

Anderson (1983: 6) described how national identity unites people across time, space, and geography. Hitherto an abstract concept, it comes to life as a social reality, gaining resonance through newspaper narratives and images, which are "... distinguished not by their falsity/genuineness, but by the style in which they are imagined." Thus, national identity becomes a social construct subject to context, debate and revision. 
Given that national identity is 'imagined,' Billig (1995) elaborated on the importance of reinforcing societal expressions of the nation. He noted how national flags hanging quietly on public buildings serve to subtly remind citizens of the wider national societies to which they belong. Flags become metonyms for nations, connecting people and unifying the mental images that people have of their 'imagined national communities.' Such symbols crystallize a 'we-feeling,' in which citizens “... regardless of actual inequality" view membership "...as a deep horizontal comradeship" (Anderson, 1983: 16). This collective 'we-feeling' is often contrasted with 'other' national identities and cultures to become an 'us versus them' comparison and discourse (Colley, 1992), so as Cohen (2000: 581) articulated "we know who we are by agreeing who we are not." Although national identity is subject to context, negotiation, and revision, it serves as an overarching affiliation defining people in their everyday lives. The strength of this emotional commitment can be measured by the numbers of people willing to make the supreme sacrifice for their nation during war (Billig, 1995).

International sport recreates that strong collective national identification and communal belonging. It transcends inequalities “...across the boundaries of structure, rank, and socioeconomic status" (Ingham and McDonald, 2003: 26). Thus, for the duration of the 17-day media extravaganza that is the Olympics, all national citizens appear to be equal as they pull for the same national team as they read newspaper articles about Team GB. They “... identify with and ... regard as their own the accomplishments of their fellow nationals" and "...by identifying with the nation ... individuals' finite lives are transcended" (Guibernau, 2007: 169). As such, Hobsbawm (1990: 143) noted "the sporting nation represents a compelling and seductive agent of cohesive commonality...it is the (symbolic) collective glue which creates the imagined community of the nation." Medal ceremonies, with their raising of national flags and playing of national anthems, become symbols of nationalism, uniting athletes and spectators in a deluge of media dramatizations. In this way Hobsbawm (1990: 143) noted how "the imagined community of millions seems more real as a team of eleven named people. The 
individual, even the one who only cheers, becomes a symbol of the nation himself." Thus, in the emotionally charged atmosphere of the Olympic Games athletes and citizens become one. As Smith (1998: 137) noted, the depth of identification with the nation "... is not only known and imagined: it is also deeply felt and acted out."

This study draws heuristic insights from the research of Edmunds and Turner's (2001) concepts of benign and malign nationalism, which they derived from interviews with seven prominent English women from the post-war elite generation to identify a common set of themes they delineated as benign and malign nationalism. They characterized English benign nationalism as open, tolerant and contributing uniquely to English/British culture. Further, they described benign nationalism as progressive and cosmopolitan because of its embrace of multicultural, multiethnic, and multi-faith influences, as well as reinforcing European laws and human rights. In the context of the LOG, benign nationalism would recognize the Olympic Charter that stresses participating over winning. Edmunds and Turner (2001) called benign nationalism 'ironic,' noting that it is a social construct and subject to constant challenge and change. This contrasts it with more ethnically based versions of nationalism that emphasize primordial descent, ethnic purity, and cultural homogeneity. Finally, Edmunds and Turner (2001: 94) define benign nationalism as 'feminine' in its approach to conflict avoidance and the creative aligning of its ideals to "... openness, liberalism and tolerance." Edmunds and Turner (2001) contrasted the tenets of benign nationalism to those of malign nationalism. In the English/British case they associated malign nationalism with a 'Little England ${ }^{1}$ mentality, the idea that the nation's lifestyles and traditional values should be protected from foreign invasion and dilution. This draws on historic images of the evacuation of British troops from Dunkirk ${ }^{2}$ at the beginning of the Second World War, and symbolizes English/British separation from a defeated European mainland. Thus, malign British nationalism is backward looking and hankers after a bygone era of traditional English/British values and symbols. It is a closed and repressive mindset. It resists Celtic nationalism, the encroaching influence of 
the European Union, and the devolutionary shift of England/Britain towards a multicultural 'community of communities'. It sees national identity as sacred and 'in the blood.' Finally, malign nationalism venerates masculine hawkishness in foreign policy dealings, especially in conflict situations.

In sum, then, the malign British identity is underpinned by the traditional values of conservatism, hierarchy, imperialism, masculinity, militarism, monarchism, racism, and xenophobia. It emerges in international sporting context as the belligerent, aggressive and tribal behaviors of England soccer supporters, with their Crusader and RAF costumes, plastic Tommy helmets, inflatable bomber planes and divisive, xenophobic chants such as 'two world wars and one world cup' and 'ten German bombers' (see Vincent and Hill, 2011). However, as Aughey (2007) noted, such boorish versions of Englishness/Britishness seem at odds with many facets of modern Britain. Reflecting this, Malcolm's (2009) examination of English national identity, cricket, and popular discourse concluded that in contrast to the sense of malign Englishness that was a feature of the English cricket team and its supporters during the last two decades of the $20^{\text {th }}$ century, in the first decade of the $21^{\text {st }}$ century, politicians, cricket administrators and journalists moderated their rhetoric, recognizing that most English and British people wished to be portrayed benignly through the lens of cricket. This study seeks to provide further insights about the benign - malign dichotomy, in this case expanding Malcolm's thesis to British identity during the home Olympics.

\section{British National Identity - A Socio-Historical Context}

The United Kingdom of Great Britain is a configuration of three unions between England and the other home nations of Wales, Scotland, and Northern Ireland, and as a composite nation, is subject to internal fissures and instability (Ward, 2004). Illustrating this, in espousing Scottish independence several Scottish nationalists (see Nairn, 1977, 2000 and Harvie, 2000), have promulgated a perception of a 'crisis of Britishness,' which has dovetailed with narratives describing Britain as a declining world power, whose best days are behind it. Several noted scholars (see Colley, 2007; Gilroy, 2005; Hitchins, 
2008; Weight, 2002) even questioned the viable future of Britain given that the pillars that originally defined it, Protestantism, the Empire, and the implied exceptionalism of an exclusionary island story narrative, had eroded in the second half of the $20^{\text {th }}$ century. Scottish political journalist and television presenter, Andrew Marr (2007) suggested that Britain had come to represent a collection of civic institutions with little underlying shared connection. He noted that the remnants of any remaining collective unity were being further undermined through devolution, the encroaching powers of the European Union, and the inexorable forces of multiculturalism and globalization. However, some academicians (e.g. Aughey, 2007; Bogdanor, 2002; Cohen, 2000; Ward, 2004) viewed the future of Britain more sanguinely, noting the country's enduring resilience and adroitness in coping with change and challenges when required.

They needed both for example as they dealt with the historically intertwined national identities of England, Wales, Scotland, and Northern Ireland during devolution in 1999 (Hayton et al., 2009). Since that time many British people have reverted to their primary identity. They have become English, Scottish, Welsh, or Northern Irish. Being British is their secondary loyalty. This has helped national independence movements such as the Scottish Nationalist Party and Plaid Cymru in Wales (Gamble and Wright, 2009). In Scotland, an independence referendum took place in September 2014. Though rejected, the issue did not go away, especially after Scotland voted to remain part of the European Union in the June 2016 Brexit referendum when the UK as a whole rejected it. Thus, as Colley (2009: 21) noted, Britishness co-exists with other identities in a "... sometimes untidy fashion." Britishness then, like all national identities, is subject to change over time (Ward, 2004). It morphed over the second part of the $20^{\text {th }}$ century as Asian immigration from former colonies challenged traditional views of Britain as a fair-skinned race. During the 1960s, right-wing politicians such as Enoch Powell made political capital out of the change (Ward, 2004). The Thatcher government of the 1980 s required immigrants to 
assimilate British cultural values, and sought to control Black and Asian immigration through strict and discriminatory immigration controls (Parekh, 2000).

Hall (2000: 617) noted that "modern nations are all cultural hybrids." Reflecting this, Cohen (2000) claimed the old 'over-assertive' British stereotype was outdated and had been replaced by a complex, fuzzy, multi-layered identity. Colley (2009) noted that the British identity has always been bonded around civic duties rather than ethnic affiliation. As such, it had always accommodated and been shaped by new ethnicities and cultures. Changes in the idea of what being British was evolved when a Labour government was elected in 1997, and it embraced a new multi-ethnic and multi-national notion of Britishness. It acknowledged the trend that British Pakistani playwright, screenwriter, filmmaker, and novelist, Hanif Kureishi (1989: 286) recognized that the indigenous “... white British ... have to learn that being British isn't what it was. Now it is a complex thing, involving new elements." However, as Rojek (2007) opined, reconciling nationalism in a multicultural and multi-ethnic society in the global era is a challenge, which became harder after Britain's support of the US invasions of Iraq and Afghanistan, the $7 / 7$ London transport bombings, and a sense of unrestrained immigration from European Union countries. In the last decade, though, many British politicians have generally been careful not to define Britishness except in more open and inclusive ways to unify and culturally fuse the nation (Uberoi and Modood, 2013).

\section{The 2012 London Olympic Games}

Modern versions of many British and now global sports were introduced in the late 19th century slightly ahead of the founding of the modern Olympic Games in 1896. Initially at least, they were grounded in the English public schoolboy ethos of fair play and sportsmanship (Colls, 2011). However, a shared sense of Britishness was slow to develop as in many sporting arenas the home nations of England, Wales, Scotland, and Northern Ireland played in separate leagues and competed against each other in international competitions (Ward, 2004). The major exception to this though is the Olympic 
Games, which provide the most visible platform for the home nations to compete under the Union flag (Llewellyn, 2012). For this competition athletes from the four home nations unified and competed together as the Great Britain and Northern Ireland team, or 'Team GB' as it was branded in 1999 (Gamble and Wright, 2009).

Given that the eyes of the world would be focused on Britain in the 2012 LOG it was the perfect opportunity to (re)image and update British identity. The opportunity to use the Olympics to reenergize the 'British brand' was seized by the British Olympic Association (BOA) in presenting their bid. The centerpiece of the bid was to revitalize a multicultural, multi-ethnic, socially deprived part of the East End of London with state-of-the-art sporting facilities to inspire grass roots sports participation (Girginov, 2013). This involved linking the internationalism of the Olympics with a new vision of Britishness that emphasized inclusion, openness, tolerance and creativity (Coe, 2012). This updated the more traditional global view of Britishness that emphasized social class hierarchies steeped in imperial grandeur (MacRury and Poynter, 2010). Outlining the new vision of the British nationality, Tessa Jowell, Olympics Minister and Secretary of State for Culture, Media and Sport declared,

...it will showcase our country as the outward looking, confident and inclusive country that we know it to be and makes us so proud to be British. ... In the $21^{\text {st }}$ century, we look much more to what is described as soft legacy - the jobs, the sporting opportunities, the skills, the sheer scale of national pride and shared memories that will bind us together as a nation throughout the lifetime of everybody who has been part of it (Jowell, 2007).

Occurring after the popular Royal Wedding of Prince William and Kate Middleton and in the immediate aftermath of Queen Elizabeth II's Diamond Jubilee celebrations, this provided a further opportunity for the British press to inject a 'feel-good' factor into a nation reeling from massive cuts in public expenditure. The British 'malaise, ${ }^{\prime 3}$ its relative geo-political and economic decline since 1945 , has been a recurring theme of anxiety embedded in the national psyche of the 'imagined community' in the national press (see Porter, 2004), and in the build-up to the home Olympics the nation's self-confidence had been dealt a series of blows over the MP expenses scandal, widespread media hacking of 
newsworthy individuals, and a severe economic recession. Concerns about government spending cuts and riots in some London boroughs and several English cities in the summer of 2011 completed the litany of events sapping British national confidence. All this contributed to a sense that the 'Great' in Great Britain belonged in the past

It was not a new problem. Successive British Prime Ministers had attempted to address this issue. In the late 1990s, Tony Blair's Labour government drew on Mark Leonard's (1997) seminal work on renewing Britishness. Attempts had been made to re-energize the national brand by celebrating British youth, pop culture and style in its 'Cool Britannia' public relations campaign (Nairn, 2000). In the 2000s, successive governments sought to define Britishness as a civic, inclusive identity and when the opportunity arose to stage the Olympics, successive Prime Ministers and Mayors of London put aside political differences and recognized the opportunity to re-position Britain as a modern, progressive British society in front of a global audience (Tomlinson, 2014).

Nothing symbolizes a nation's health and vitality like athletic success which allows the nation to collectively bask in the reflected glories of its athletes' victories and to commiserate with gallant failures and losses (Weight, 2002). Since 2005 when Britain won the bid to host the Olympics, UK Sport, which receives centralized funding from the Lottery, invested $£ 550$ million in British Olympic and Paralympic athletes expected to compete for medals for Team GB at the 2012 home Olympics (Collins and Cruickshank, 2013). With the benefit of home advantage, UK Sport set a target of finishing in the top four of the medal table and winning at least one more medal than the 47 won in the 2008 Beijing Olympics (Collins and Cruickshank, 2013). Thus, for the 17-day duration of the LOG, Team GB athletes would become in some ways personifications of Britishness, which would make their success or failure, as well as their deportment as national role models and 'patriots at play'4 the subject of intense media scrutiny. 
Guibernau (2007) noted how traditionally the image of the nation is usually reflected in earnest, insular narratives about the indigenous population and dominant racial and ethnic group. However, in the LOG, many of Team GB athletes, such as Jessica Ennis and Mo Farah, reflected the evolving pluralization, hybridity, and multicultural makeup of modern Britain. In an attempt to build on the successes of the Beijing 2008 Olympic Games, the BOA appointed Charles Van Commenee, a widely respected Dutch coach as Head of British Athletics. Illustrating how British identity is contested, in the lead up to the LOG, controversy unfolded when it was widely reported in the media that Van Commenee had overseen the recruitment of 61 athletes who were born abroad and represented the embodiment of modern diasporic athletes. These athletes, pejoratively dubbed 'plastic Brits,' in malign newspaper narratives, qualified to compete for Team GB in the 2012 home Olympics through family lineage or naturalized citizenship (Poulton and Maguire, 2012). In the build-up to the LOG it was argued in the British press, particularly the Daily Mail and The Sun, which is known for its parochial 'little Englander' discourses, that transnational 'plastic Brits,' who are not really 'one of us,' were stifling opportunities for 'homegrown' British athletes (Vincent and Kian, 2014). Prominent among the so-called 'plastic Brits' accused of flying the British 'flag of convenience' was Tiffany Porter, born to a Nigerian father and English mother and raised in Michigan in the United States. When Porter became captain of the British athletics team for the World Indoor Championships in March 2012, she was roundly criticized in the British press for her inability to demonstrate her British credentials and assimilation of British culture in a press conference by failing to recite the first few lines of God Save the Queen, the British national anthem. Des Kelly, a Daily Mail sports columnist, even questioned world class 10,000 and 5000 meter runner, Mo Farah's British credentials, noting he was born in Somalia and trained in Portland, Oregon. However, most British journalists claimed Farah as 'one of ours' because he had been brought up in and assimilated British culture, rather than using Britain as a flag of sporting convenience. The "plastic Brits" discourses revealed the malign, divisive, exclusionary, and contested nature of British identity politics, 
and how "... right-wing perceptions about ... Britishness ... are underscored by an anti-multiculturalism that struggles to celebrate dual-nationals as truly one of us" (Poulton and Maguire, 2012: 11).

\section{The London Olympiad, National Identity, and the Media}

Boorstin (1961) described major international sporting events as 'pseudo-events' because of their penchant for garnering extensive media publicity. Billings (2008) agreed, dubbing the quadrennial Olympic Games as 'the biggest show on television'. It was not surprising then when the British

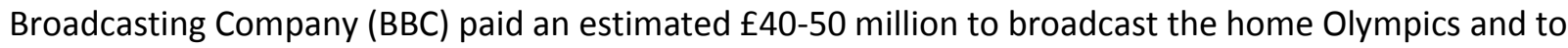
present an unprecedented 5800 hours of sports over the duration of the Games (Magnay, 2010). Over the 17-day sporting extravaganza, with an estimated 21,000 journalists covering 10,500 athletes competing from 204 nations, the eyes and ears of all sports journalists and multimedia companies worldwide were focused on London and Britain, entertaining and indulging their publics with nationalistic, nostalgic, and dramatic narratives and images (Girginov, 2014a).

Reflecting the significance of the home Olympics British newspaper coverage moved well beyond the usual confines of the sports pages. Supplements and souvenir sections in print and digital formats allowed people to follow the drama of British athletic successes and failures, as the Olympics became a powerful prism through which national identities were refracted. Editors and journalists of all nations played pivotal roles in constructing and deconstructing shared meanings about what their countries were and what they stood for, all recounted through the emotionally charged atmosphere of international sport. For the London-based British press in particular, the LOG became the ideal medium, in an era of declining circulation, to not only to sell print newspapers and electronic format subscriptions but also to present their views on Britain and what it now stood for. The London Olympics, therefore, presented the ideal backdrop to examine how newspaper narratives about British national identity politics are (re)presented.

\section{Methodology}


This study employed textual analysis to examine how British national identity was (re)constructed during the 2012 LOG in British newspapers. We examined hard copies of two broadsheet newspapers, The Times and The Daily Telegraph, and three popular (tabloid) newspapers, The Daily Mail, The Sun, and Daily Mirror. The newspapers were chosen because of their national prominence and extensive sports coverage and were collected every day for the duration of the LOG, which was held from 27 July-12 August, 2012. In total, we examined 90 newspapers.

The textual analysis used inductive open and axial coding. Open coding was initially used to note recurring themes and identify dominant narratives as well as contradictions and inconsistencies. Drawing on the methodology outlined by Creswell (2003) and Strauss and Corbin (1999), this initial form of coding utilized a constant comparison means of analysis to generate emergent themes before incorporating axial coding to link previously identified themes and categories within the data (Strauss and Corbin, 1999). Through axial coding, specific codes were developed across transcripts and subsequently analyzed according to the larger theoretical frameworks of British nationality. The overriding frameworks of Britishness used were Anderson's (1983) theory of the 'imagined community' and Edmunds and Turner's (2001) concepts of benign and malign nationalism. This methodology does not aim to reproduce the newspapers' coverage or reporters' narratives, but, rather to uncover the textual constructions of national identity permeating the dominant discourses.

\section{Results}

Theme 1: "Welcome to these, our Isles of wonder"

Since Britain's 'finest hour' ${ }^{5}$ in the Second World War there has been a prevailing sense that Britain has been in decline (Porter, 2004). Indeed, British social anthropologist, Kate Fox (2004) identified an underlying sense of national skepticism, pessimism, and anxiety that things will always go wrong and 'to expect the worst'. Reflecting this, an editorial in The Daily Telegraph reminded its readers that the nation "... seemed unsure of its place in the world" and that many Brits thought that "...London 
2012 would be a flop - that a dismal, second-class nation such as Britain could never raise its game to the required heights" (4 August 2012: 23). Paul Kelso, chief Olympic correspondent, recapped how Britain “...may have invented the Olympic sports," but "...had long forgotten how to win them or build stadiums to play in" (The Daily Telegraph, 27 July 2012: S5). However, Olympic opening ceremonies usually furnish host nations with opportunities to positively showcase their history, national culture and greatest achievements to a global audience and the London Organizing Committee of the Olympic Games (LOCOG) spent an estimated $f 27$ million on the "Isles of Wonder" opening ceremony, a theme inspired by William Shakespeare's play The Tempest. Scripted by novelist Frank Cottrell Boyce, with costumes designed by Suttirat Larlarb and directed by Danny Boyle, well-known for his direction of Train Spotting and Slumdog Millionaire, the ceremony choreographed famous scenes and achievements from Britain's past. The opening scene showcased Britain's eccentric sense of humor in a pre-filmed spoof sequence featuring the British actor Daniel Craig, in his role as fictional spy James Bond, and the Queen, a symbol of reserved British tradition, cast in a new humorous light, appearing to enter the Olympic stadium in a parachute. In contrast to showcasing Britain's imperial history and military victories, the story the nation choose to tell itself and a global audience contained four main acts, which featured the English/British countryside, the industrial revolution, the National Health Service (NHS), and children's literature all fused within a backdrop of British music.

Many British press reviews showered Boyle's opening ceremony with praise. A Daily Telegraph alliterative headline described it as "BRILLIANT, breathtaking, bonkers and utterly British" (28 July 2012: 4). Several editorials suggested Boyle receive formal recognition for his services in the form of a knighthood for distilling "... the best of British culture into an amazing show" (The Sun, 28 July 2012: 10). Many narratives reflected how "... the many layers of our national identity was perfectly reflected by the ... ceremony's blend of whimsy and spectacle" (The Daily Telegraph, 4 August 2012: 23). No congratulatory adjective was left unwritten, including: open, liberal, tolerant, inclusive, cosmopolitan, 
multicultural, ironic, quirky, humorous, self-deprecating, understated, and creative. All praised Boyle's selective cornucopia of Britain's past, present and future underpinned in a benign version of Britishness. Boyles "Isles of Wonder" largely glossed over any injustices, misdeeds, crimes, or atrocities perpetrated in the name of the British Empire or in military exploits and focused instead on British liberal democratic values, inventive creativity, and global contributions. Echoing the consensus of British press opinion about the benign opening ceremony, The Sun's guest columnist, Richard Bacon, an English television and radio presenter, quoted a tweet from lan Watson describing the opening ceremony thus, "It was brilliant because it reclaimed patriotism from swivel-eyed loons and recast it as love of pride in your fellow people" (2 August 2012: 15).

Given the contested nature of what modern Britain represented and the combative nature of the British press, as expected, there were counter narratives. Several journalists criticized the celebration of British humor, self-mocking irony, self-effacement, and eccentricity, suggesting it may have been too esoteric for a global media audience. Several conservative editors, journalists, and politicians criticized its bowdlerized “...nostalgia of the NHS" (Daily Mail Comment, 4 August 2012: 16) and "... re-fashioning of history," which minimized several "...traditional symbols of patriotism" (Daily Mail, 2 August 2012: 19) and subverted "... the inflated, martial spectacles that custom usually demands" (The Daily Telegraph, 4 August 2012: 21). Most newspapers reported how Michael Gove, Secretary of State for Education, had expressed disquiet about the absence of British wartime Prime Minister, Winston Churchill, a strong advocate of the Empire and defender of Anglo-Saxon values, after viewing a rehearsal. Some journalists critiqued that the benign opening ceremony was underpinned by the civic values and consciousness, including the constitutional democratic principles that protect citizens' rights and freedoms and underwrite social cooperation, which could apply to almost any Western European national identity. They similarly condemned aspects of the ceremony deemed tainted by Boyle's left-wing political ideologies. They objected to the focus on 1948 as the pivotal year 
in modern British history, when Attlee's Labour Government created the National Health Service and the first wave of Caribbean immigrants came to Britain. In British conservative national identity politics, multiculturalism is often perceived to be a euphemism for the dilution of traditional Englishness (see Burdsey, 2016), and reflecting this all the sampled newspapers reported how Aidan Burley, a British Member of Parliament tweeted, "The most leftie opening ceremony I have ever seen-more than Beijing, the capital of a communist state! Welfare tribute next?" Burley then added a second tweet: "Thank God the athletes have arrived! Now we can move on from leftie multi-cultural crap. Bring back the red arrows (sic), Shakespeare and the Stones!" (Daily Mail, 30 July 2012: 10). However, Burley's tweets were roundly criticized by leading Conservative politicians including David Cameron, the Prime Minister, and Boris Johnson, the Major of London, and in an interview with his biographer Amy Raphael (2013: 411-412), Boyle responded, "The values espoused by the opening ceremony are not left-wing values. They're more to do with that fact that we can be a modern, progressive country, and as such we can be an inspiring beacon for people everywhere."

Theme 2: A Benign Britain looking for a Great Briton

Buoyed by Boyle's widely acclaimed, progressive, uplifting opening ceremony, the narratives mainly projected a benign Britishness. Reflecting this, David Hannan, Conservative Member of the European Parliament (MEP) for South East England, noted the benign outpouring and expressions of patriotism the home Olympics generated. He recalled how, before the first event, the men's road race through the leafy suburbs of Surrey, every house lining the route had a Union flag. He observed how spectators shared "...drinks and sandwiches with strangers" and noted how, even when foreign cyclists "flashed past," it "... made little difference to the mood. People had been celebrating their common identity with one another, not just Britain's sportsmen." He concluded, “The Olympic Games have brought British patriotism back into fashion: British patriotism in its broadest, most benevolent, most generous form" (Daily Mail, 7 August 2012: 14). Paradoxically, the narratives also reflected an 
expectant home nation "looking for a British hero" (The Sunday Times, 29 July 2012: front page). In contrast to French aristocrat Baron Pierre de Coubertin's original Olympic egalitarian ethos, that what was important was not winning but taking part (see Jenkins, 2005: 142), the elitism of Olympic competition came to the fore in partisan newspaper narratives as the LOG provided a perfect platform for demonstrating national sporting prowess and for fostering national sentiment in an 'us versus them' binary narrative. Further, as Andrews and Rick (2014: 196) noted, “... the Olympic Games provides a seductive and effective platform for the production and dissemination of celebrated persona." Accordingly, British journalists, charged with the important role of creating national sports heroes for the 'imagined community,' were steadfastly focused on the relatively few out of the British contingent of 542 Team GB athletes that were in contention for medals. Reflecting this, The Daily Telegraph columnist, Mathew Norman, remarked that

....any eruption of national pride will be reserved for the first time one of our athletes stands on the top shelf of the podium blinking back the tears as the Union Jack climbs the flagpole....It is impossible not to love a compatriot with a gold medal around their neck (28 July 2012: 21).

Demonstrating the benign, deprecating, ironic, quirky British humor celebrated in the opening ceremony, at the outset of the Games, Boris Johnson, the then Mayor of London, issued a tongue-incheek prediction that Britain would do well in the sitting down sports it had targeted to medal in “...cycling, rowing, sailing and riding" (The Daily Telegraph, 30 July: 16). But the old British pessimism persisted. Reflecting on Britain's lack of early success, Derek McGovern, the Daily Mirror's sport betting tipster claimed, only half-jokingly, that Team GB stood for "Getting Beaten" (1 August 2012: 60), while The Sun's Ryan Sabey suggested that the 'imagined communities' “...nerves can't stand much more" and colloquially urged Team GB to "GISSA gold” (31 July 2012: front page).

On day six the tide changed and The Daily Telegraph's chief sports writer Paul Hayward noted the cathartic moment when community 'despair' veered to 'euphoria' with the first British gold medal. Predictably, the "seminal moment for these Games" came in a "sitting down sport" (2 August 2012: 2) 
when Helen Glover and Heather Stanning won the women's rowing pairs. A jubilant 26,000 spectators, including Prince William and Prince Harry, witnessed the event. Hayward exuberantly declared, "This was for the whole team and the whole country," which sparked delirious scenes of "mass elation" and “... rejoicing at the Eton Dorney rowing lake" ${ }^{6}$ (2 August 2012: 2). The Time's Matt Dickson described the scene by the rowing lake as "thoroughly British" as "pent-up anxieties were unleashed in a great rush of relief, joy and national pride" as "...two smashing women won the first British gold" (2 August 2012: 8). Commentating on their victory, and illustrating the ingrained connection public schools, sport, and national self-assertion and prestige hold in the British imagination, the Daily Mirror's Oliver Holt could not resist evoking the 'invented tradition' of the Duke of Wellington's oft-quoted, elitist claim that the Battle of Waterloo was "...won on the playing fields of Eton and now the London Olympics have been rescued on its rowing lake" (4 August 2012: 10). These celebratory, comforting, and inclusive narratives largely ignored that the scenes at Eton Dorney were more representative of the exclusive, predominantly White and prosperous upper-middle-class socio-economic demographics of the English Home Counties ${ }^{7}$ that surround London, and that like many of the 542 athletes representing Team GB, Helen Glover and Heather Stanning, had been privately educated at prestigious, highbrow public schools, Millfield and Gordonstoun, ${ }^{8}$ respectively.

In the aftermath of Glover and Stanning's victory most newspapers reported how Lord Moynihan, the Chairman of the BOA, was critical of how more than half of Britain's gold medals in the 2008 Beijing Olympics had been won by athletes who were products of costly private schools, often in sports that required considerable financial resources. Given that only $7 \%$ of British students attended private schools, Moynihan called for an overhaul of public school sport policy. Claiming he personally benefited from competitive school sports each day, Boris Johnson, the London Mayor and the product of a privileged Eton upbringing, was also widely quoted advocating the populist position of the reimposition of the two-hours of school sports each day. Finding humor in this social issue, under the 
headline, "Does everyone in England go to school at Eton?" Daily Mail columnist and satirist Richard Littlejohn parodied a fictional American journalist who wondered how in a celebration of British diversity, it seemed like half the British athletes went to Eton (10 August 2012: 17).

In cycling, Paul Kelso, sports reporter for the Daily Telegraph, noted how "anxiety about Bradley Wiggin's prospects in the time trial had increased with every day that passed without a British Gold" (2 August 2012: S5). On the same day, Paul Hayward chronicled how Wiggins, who had won the grueling Tour de France 10 days earlier, was spurred on by very loud British spectators sporting fake Wiggins sideburns while waving Union flags, to win the men's individual cycling time trial (2 August 2012: 2). Rojek (2001: 52) noted how in the cultural politics of sporting celebrity and national identity, sport stars offer "powerful affirmations of belonging, recognition and meaning." Reflecting this, the front page of The Sun on the 2 August 2012 edition had a photograph of Bradley Wiggins sitting on a throne at Hampton Court Palace, saluting the crowd and photographers with iconic Churchillian victory salutes ${ }^{9}$ under the headline "G0000000000OLD!" In the same edition, The Sun's chief sports reporter Steven Howard saluted Wiggin's achievement as the first cyclist ever to win the Tour de France and an Olympic gold in the same year. Howard, a journalist for over 30 years, concluded, "As the country in general, and the roads round Henry VIII's old palace at Hampton Court in particular, were bought to a halt, you searched in vain for a more glorious moment than this for any individual sportsman" (2 August 2012: 63). The Daily Telegraph's chief sports writer, Paul Hayward, embraced Wiggins's working class credentials and humility, and enthused about how after his gold medal win at the Hampton Court Palace cycling venue he was "...embraced as alternative sporting royalty." He described Wiggins as "funny" and "irreverent" and how he "...appeals instantly to British sports fans, who tend to warm to people they could imagine having a pint with" (2 August 2012: 2).

In those early days of London 2012, Glover, Stanning and Wiggins, although products from different backgrounds became exemplars of British sporting exceptionalism as the nation basked in their 
reflected glory. Their gritty performances and down to earth, unassuming behavior, chronicled in the newspaper narratives, made them easy to identify with. Their gold medal performances would be celebrated nationally through the 'invented tradition' of a special set of Royal Mail stamps. Haywards concluded how “... on this special day, the whole country won" (2 August 2012: 2).

The success of the first gold medal performances by Glover, Stanning and Wiggins marked a pivotal turning point with an increasing number of enthusiastic self-congratulatory narratives that romanticized successful Team GB athletes, who were extolled as exemplars of British values that captured the imagination of the British public, and inspired a mood of celebratory patriotism. Uplifting feel-good stories were fed to the 'imagined community' about the inspirational, dedicated, self-effacing British athletes from all the home nations. How they radiated human warmth whilst living up to the Olympic ideals of sacrifice and determination, dedicating their lives to rigorous training regimes often without major financial rewards, was contrasted favorably to the behavior and lavish lifestyles enjoyed by highly paid professional footballers. Superlatives abounded about their "sheer decency," "their modesty in victory" and "...unself-pitying in disappointment" (Daily Mail, 4 August 2012: 16). They epitomized the best of traditional British public school values in both victory and defeat, and a sense “...that there's still a Britain in which we can all take pride" (Daily Mail Comment, 4 August 2012: 16). Such commentaries were in stark contrast to the corrosive tribal expressions of popular English national identity associated with the English national soccer team and their fans during unsuccessful World Cup and EURO tournaments (see Maguire and Poulton, 1999; Vincent and Harris, 2014; Vincent et al., 2010). Theme 3: 'Us versus Them': We Can Do Malign Britishness Rather Well, Too Although many of the themes found in the narratives accentuated benign versions of Britishness, the complex, defensive, and divisive nature of British identity politics was also revealed, highlighting both internal and external divisions. 
For the first time since 1960, a Great Britain football team competed in the Olympics, with teams in both the men's and women's competitions. However, the development of the teams was not universally accepted because in other international football tournaments, the home nations of the United Kingdom (England, Scotland, Wales and Northern Ireland) were represented by their own national teams. ${ }^{10}$ The difficulty encountered in selecting Northern Irish, Scottish, Welsh and English players for a combined Team GB, dominated with English players, illustrated the complexity and contested nature of British identity politics, in which "people define themselves in opposition to other nationalities in the UK" and "... claims for sameness and differences are ... made" (Malcolm, 2009: 615). The difficulty in fostering an overarching, shared British identity in this context was illustrated in the Olympic football matches during the pre-game ritual of playing each team's national anthem, which can publicity emphasize either unity or dissent as football players' deportment and behavior as 'patriots at play' becomes the subject of intense media scrutiny.

In the build up to the LOG Daily Mail sports columnist, Des Kelly displayed an insular, malign Britishness when he questioned the authenticity of the so-called 'plastic Brits,' suggesting they were not really 'one of us.' In a similar vein, during the LOG, under a headline "Let's hear it if you're British" Kelly displayed a displayed an Anglocentric version of Britishness when he criticized the male Welsh football (soccer) players Ryan Giggs, Craig Bellamy, Joe Allen, and Neil Taylor, and female Scottish players Kim Little and Ifeoma Dieke for not publicly demonstrating their patriotism by singing the British and English national anthem God Save the Queen before their respective Team GB matches (28 July 2012: 99). Kelly clearly expected the Welsh and Scottish players to subsume their Celtic home nation identity in favor of an overarching British identity for the pre-game ritual. The Daily Mail described how Ifeona Dieke was born in Massachusetts to Nigerian parents and elected to play for Scotland, where she had lived since she was a small child, rather than the United States. The same article reported how Kim Little's family claimed that, as a Scot, she objected to the alternate and seldom sung fifth verse ${ }^{11}$ of the anthem, 
penned in 1745, which expressed anti-Jacobite sentiment and the words 'Rebellious Scots to crush' (27 July 2012: 4). Welsh players Giggs, Taylor, and Bellamy, who all played for English clubs, responded that singing the British and English national anthem instead of the Welsh national anthem, Land of My Fathers, was difficult and not something they felt they could join in with their English teammates. The complexity of integrating Welsh and Scottish players into Team GB was a challenge because for many Welsh and Scottish players and fans alike, their sense of Britishness was less meaningful than their Welsh or Scottish identity. Illustrating this, ahead of Team GB men's third match, played at the Millennium Stadium in Cardiff, Wales, several newspapers reported how Ryan Giggs felt compelled to urge Welsh fans not to boo the performance of the British and English national anthem.

Several vitriolic adversarial 'us versus them' exchanges were reported between British politicians and their counterparts in the United States and France. Every newspaper examined reported the Republican US Presidential candidate Mitt Romney's "clumsy diplomatic touch." Visiting London on the eve of the Olympiad, Romney disparagingly opined that preparations for the LOG were "disconcerting" and he didn't know “...how well the Games would turn out” (The Times, 27 July 2012: 12). His comments hit a collective British nerve. Jon Swaine, The Daily Telegraph's New York correspondent, noted how this brought a defensive, terse retort from the British Prime Minister, David Cameron, who was quoted responding, "We are holding an Olympic Games in one of the busiest, most active, bustling cities anywhere in the world. Of course it's easier if you hold an Olympic Games in the middle of nowhere" (27 July 2012: 4). This was a reference to the sparsely populated state of Utah, which hosted the 2002 Winter Olympic Games under Romney's direction. Sunday Mirror journalist Mark Austin similarly criticized the organization of the 1996 Centennial Atlanta Olympic Games, and concluded "we don't need an American to come over here to tell us that we are not ready for the Games" (29 July 2012: 14). Under the headline "Mitt the Twit" Graeme Wilson, The Sun's deputy political editor, described how Romney "... also questioned" whether the British people will "come 
together and celebrate.” He further noted how Boris Johnson, the Mayor of London “...publicly ridiculed" Romney to popular acclaim to a crowd at a concert in London's Hyde Park (27 July 2012: 6). Jeremy Clarkson, the host of Top Gear, the iconic British television show about cars, was reported to have caustically tweeted, "My ideas for the opening ceremony were rejected. I suggested we should crash a burning Jag into Mitt Romney" (The Times, 29 July 2012: 8). Lucy Bannerman, home news reporter for The Times, described how a British couple interviewed in the Olympic Park expressed optimism and pride noting that "regardless of what Mitt Romney might think, the British can do these things well" (28 July 2012: 10).

A recurrent tension found in the newspaper narratives was the contradiction between the Olympic charter ideals influenced by the British sense of fair play and being a good sport, which originated on the playing fields of Eton and Harrow in the late $19^{\text {th }}$ century, and the intense competitive desire to gain every advantage to win and facilitate a national feel-good factor (Tomlinson, 2014). The BOA bid was won against fierce competition, beating its closest rival, Paris, by four votes and Daily Mail columnist Robert Hardman detected some "sour-grapes" in several French responses (9 August 2012: 15). Before the LOG, David Cameron, the Conservative British Prime Minister, aggravated newly elected socialist French President, Francois Hollande, when he offered to roll out the red carpet to disaffected French entrepreneurs and firms upset at Hollande's newly imposed top rate of tax. Hollande responded when on the fifth day of the Olympics the French President '...jokily thanked Britain for "rolling out the red carpet" for French athletes' to win a number of medals. At the time this placed France third in the medal table while Britain languished in $21^{\text {st }}$ position (Daily Mail, 1 August 2012: 10). Hollande further provoked British conservative Euro-sceptics when he said: "We will put the French medals into the European pot so that the British will be happy to be European" (Daily Mirror, 1 August 2012: 6). Nationalistic tempers became further frayed between the French and British sporting contingents after cyclist Chris Hoy won the sixth gold medal of his illustrious Olympic career in the men's 
keirin. This underpinned British dominance in a sport long considered a French specialty as Team GB won seven of the ten gold medals contested at that point. Under the headline "I hate French whine" Mark Irwin, The Sun's football correspondent, described how L'Équipe, the French sports newspaper mischievously questioned, "Are the British cycling performances stained by cheating?" (9 August, 2012: 6-7). Invoking the epithet, 'Perfidious Albion,' which originated from French and Spanish perceptions of British duplicity during the Napoleonic Wars (see Rojek, 2007: 112), Isabelle Gautheron, the French cycling team director, was quoted complaining that British cycling dominance may have been “.... down to illegal technology" because "the British hide their wheels a lot. The ones they use for the bikes they race they put in the covers at the finish" (9 August 2012: 6). Dave Brailsford, the Team GB cycling performance director, was humorously reported to "... have wound up a gullible French interviewer by joking that ... specially round wheels were the key to Britain's gold rush" (The Sun, 9 August 2012: 6). Buoyed by stellar medal winning Team GB performances David Hannan, the Conservative MEP for South East England, reflected a sense of schadenfreude when he opined,

...while it would be un-British to gloat, I think we can be forgiven a certain inner satisfaction, after French President Francois Hollande's boast about rolling out the red carpet for his own country's victorious athletes, at the way we are thrashing the French (Daily Mail, 7 August 2012: 14).

Journalistic accusations and ripostes were exchanged again when the British cycling team known for its high "... standards in professionalism and attention to detail” "...exploited a loophole" when socalled 'plastic Brit,' Philip Hindes, a member of the British men's cycling sprint team, admitted in front of a television camera that he deliberately crashed after a poor start to get a restart in a heat. Hindes, a dual national, was born in Germany to a German mother and RAF airman, and competed for Germany until 2010, when he joined British Cycling's academy programme, and challenged traditional understandings of British sporting heroism narrative formations. Under a headline "Cheating? It's all foreign to us," Des Kelly, a Daily Mail sports columnist, noted how a British cycling spokesman quickly went into public relations damage control when he "...retreated behind a cover story that Hindes was a 
bit too foreign to understand or explain himself." For the entertainment of his readers, Kelly sarcastically compared this to an episode of the iconic British popular television show from the 1970s, Fawlty Towers: 'Lost in translation?' Not since Basil Fawlty hit Manuel on the head with a spoon and explained "Don't worry, he's from Barcelona" had there been a more comical excuse' (4 August 2012: 101). Kelly, who in the buildup to the Games had been one of the journalists critical of 'plastic Brits' that he claimed are not really 'one of us,' noted how Hindes almost cost the Scottish and British national treasure Chris Hoy, a historic victory. He likened Hindes' deliberate crash to the poor sportsmanship of a professional football (soccer) player taking a dive. Hoy, Hindes, and Kenny went on to win the team sprint final against, of all nations, France, and Kelly noted how if the French had "pulled this trick'" Team GB would have vehemently complained until the next Olympics. Kelly's damning indictment highlighted the hypocrisy of the malign 'us versus them' national identity politics, noting that: "when Hindes was winning gold he was British. When he took a dive he was German" (Daily Mail, 4 August 2012: 101). Theme 4: Super Saturday: A symbol of a progressive, hybrid Britain In what became known as 'Super Saturday,' the narratives about the gold medal winning performances brought 'old' and 'new' versions of Britishness together. It featured an indigenous, White Briton, Greg Rutherford, and two hybrid Brits, Mo Farah, a transplanted Somalian Muslim, and Jessica Ennis, of mixed-race, working class descent, and framed them as symbols of modern Britain. It also illustrated how “...sport can bring unscripted drama of the most compelling kind" (Simon Barnes, The Times, 27 July 2012: 29). Team GB's six gold medals in one day made 'Super Saturday' Britain's most successful day at an Olympics since 1908.

'Super Saturday', the middle Saturday of Olympic competition, was so-named because it was the day when the greatest number of medals were to be won. It also featured a number of Britain's best medal prospects competing during television primetime. Not surprisingly, 'Super Saturday' was billed as a defining day for the host nation. It began well. In the morning on the river at Eton Dorney, British 
oarsmen Alex Gregory, Tom James, Pete Reed, and Andrew Triggs-Hodge won the men's coxless fours rowing. Shortly after, Katherine Copeland and Sophie Hosking won the women's lightweight double sculls. However, there were also disappointments. As sports columnist Andy Dunn noted, there were not "... just tears of joy" (Daily Mirror, 6 August 2012: 71). Zac Purchase and Mark Hunter were favorites in the men's lightweight double sculls, but despite leading for most of the race they were overhauled in the final meters to finish second. Journalist Malcolm Folley reported on how Purchase and Hunter's nobility in defeat touched the British nation. Barely able to stand, distress written all over their faces, they apologized in the post-event TV interview for letting the nation down (The Mail on Sunday, 5 August 2012: 7). The raw emotion of the moment was captured as the experienced sport journalist, John Inverdale could not conceal his own emotions and was widely reported as muttering "Emotions, goodness me ... It's quite hard being here as well" as he too broke down in tears (Daily Mirror, 13 August 2012: 5)

Further British success followed the emotional scenes at Eton Dorney in the afternoon with a dominant performance at the velodrome as Dani King, Laura Trott, and Joanna Rowsell won the women's team pursuit cycling, breaking the world record twice in a 2-hour period before a 'deafening crescendo' of support. The newspapers reported how Britain's triumphs at Eton Dorney and the velodrome filtered through to thousands of eager spectators making their way to the Olympic stadium, there to see British hopeful Jessica Ennis run the 800 meters, the final event of the heptathlon, and Mo Farah run in the 10,000 meters in the evening. UK athletics performance director, Charles Van Commenee, recalled that there "... was the sensation that a whole nation was living the moment, both inside and outside the stadium, and it felt incredibly emotional" (Chadband, 2012).

'Our Jess.' In the build up to the LOG, Jessica Ennis, the daughter of a Jamaican-born painterdecorator and an English social worker, was billed as the "...Sheffield ${ }^{12}$ girl next door" who became the "Face of the Games" (Daily Mail, 4 August 2012: 106). Reflecting her status, there was a large image of 
her painted by British Airways on a field in Hounslow below the flight approach to London's Heathrow airport, with the caption "welcome to our turf" (The Daily Telegraph, 5 August 2012: 2). As Ennis did not compete in the 2008 Beijing Olympic Games after injuring her ankle, this would be her first and possibly career-defining Olympics. Despite being one of the world's finest female athletes, victory was “...far from a foregone conclusion" (Daily Mail, 3 August 2012: 13). For two days, though, she would shoulder the burden of a nation's hopes over the seven grueling events that comprise the heptathlon. On the eve of 'Super Saturday" chief sports writer Simon Barnes explored the notion of Ennis as an exemplar of modern Britishness:

We love Jess because Jess is Jerusalem ${ }^{13}$ : beautiful, talented, vulnerable, a perfect emblem of the green and pleasant land we long to live in. She is us. She is the people we would like to be, the place we would like to live in. (The Times, 3 August 2012: 3)

Barnes noted that she had been beaten at both the 2011 World Championships in Daegu, South Korea, and the World Indoor Championships in Istanbul, Turkey in March 2012, and how “...her petite five foot, five inch frame" made her "... look like an underdog" against taller, "Amazonian" opponents. He noted how her multiracial background made her the perfect symbol for contemporary Britain "... and its mongrel relish for a fight," which would make a victory "... something to treasure" (The Times, 3 August 2012: 3).

In the evening, Ennis, "... famed for her washboard stomach," duly won the heptathlon. She did it in style, sealing her gold medal in front of "an electrified" 80,000 fans in the Olympic stadium with an impressive win in the final event, the 800 meters. As she crossed the finish line at 9:02 p.m., she "captured the country's heart" (Daily Mirror, 5 August: 71). The Daily Mirror's chief sports writer, Oliver Holt, noted how Ennis did not need first place in the 800 meters to win the gold, but described how after being overtaken with 300 meters to go, Ennis "looked majestic" as she passed the leaders in the home straight looking "... small and slight beside the giants who were her rivals, but utterly indomitable" (6 August 2012: 60). Athletics correspondent, Simon Hart applauded “... a virtuoso performance that 
confirmed her as the greatest all-round female athlete Britain has produced" (The Sunday Telegraph, 5

August 2012: S2). UK athletics performance director, Van Commenee, concurred and declared

What made her performance extra special for me was that, more than anybody else, people expected her to win, she was the face of the Games and, effectively, she could only lose.... She was in an event where you have the chance to mess up seven times and yet still she never faltered. Amazing grace under pressure. Absolutely immense. (Chadband, 2012)

Under the headline "She's Jess Perfect" sports columnist Andy Dunn enthused about Ennis's

"performance of a lifetime" and noted how her "...tears of unconfined joy" were mirrored "... in the stands" where "... people wept with her" as a tangible sporting representation of a modern, progressive Britain (Sunday Mirror, 5 August 2012: 5).

Rutherford-"the Ginger Wizard." Sandwiched between Ennis's heptathlon gold and Farah's 10,000 meters race, Greg Rutherford, a redheaded British long jumper from Milton Keynes, ${ }^{14}$ won the second British track gold medal in an hour at 9:24 p.m. Nicknamed the "Ginger Wizard," journalist Ralph Ellis described how, with most of the nation's attention focused on Ennis in the heptathlon and Mo Farah in the upcoming 10,000 meters, "Rutherford had come into the stadium under the radar" (Sunday Mirror, 5 August 2012: 4). With the crowd still buzzing from Ennis's victory, Rutherford put in a jump of 8.31 meters. As the 10,000 meter runners warmed up, Rutherford then had to stand by and watch as each of his rivals failed to better his jump. As the tension built, Sebastian Coe, chairman of LOCOG, was later quoted acknowledging the supportive, fair-minded nature of the quintessentially British crowd, who although “...partisan ... cheered every jumper as they went down the runway, which reinforced the notion that... the best of British did not need to only hail the best of British" (Chadband, 2012). Thus, Rutherford became Britain's first long-jump Olympic champion since Lynn 'the Leap' Davies at the Tokyo Olympics in 1964. After the disappointment of a pulled hamstring before the 2011 World Championships in Daegu, South Korea, the narratives enthused about his dedication and perseverance in re-jigging his take-off technique under the tutelage of his American coach Dan Plaff. 
Mohamed Muktar Jama Farah aka "Magic Mo"- "He's Ours, Ours, Ours."-- Crowning “...the most extraordinary 45 minutes British athletics will surely ever witness" Mo Farah became the first Briton to win the Olympic 10,000 meters at 9:47 p.m. (Daily Mail, 5 August 2012: 4), and in doing so “...he seemed the embodiment of the core pledge ... - that London 2012 would inspire a generation" (Daily Mail, 6 August 2012: 10). Many newspapers recounted how Farah, born in war-torn Mogadishu, Somalia, moved to Britain to join his father, a British citizen, when he was eight. He grew up in Hounslow, west London, where his athletic potential was identified, nurtured, and developed. However, in 2011 Farah moved to Portland, Oregon, in the United States, to train under legendary Cuban-born coach Alberto Salazar to prepare for the London Olympics. This caused Daily Mail Olympics correspondent, Jonathan McEvoy, to bring to mind the pre-Games discourse of 'plastic Brits' and acknowledge Farah's potential outsider status, which was 'London-raised' but "shaped for greatness across the Pond" (13 August 2012: 60). However, in contrast to the 'plastic Brit' jibes directed at Farah before the home Games questioning Farah's Britishness, during the Games the newspaper narratives chose to celebrate his British cosmopolitan, hybridity.

The Daily Mail's chief sports writer, Patrick Collins, viewed Farah's historic win in the 10,000 meters as "... a tactical master class." He described how Farah masterfully "... covered the breaks, adjusted the pace and "... tailored the race to his demands" (5 August 2012: 3). The Daily Mail editorial evoked the classic Shakespearean vernacular from Henry V, Act 111, Scene 1, when Henry famously inspired his troops before battle at the siege of Harfleur, in describing how Farah "...strained every sinew to win Britain's sixth gold medal on 'Super Saturday,'” (11 August 2012: 16). In one of the defining images of the London Olympiad, Farah demonstrated his pride in his British nationality as he metaphorically and literally wrapped himself in the Union flag after his success. For this he was widely praised in newspaper narratives as evoking the kind of diversity celebrated in the opening ceremony. The Sun's Chief feature writer, Oliver Harvey, claiming him as 'one of ours' noted how after winning the 
10,000 meters Farah's “... reaction was to fall to his knees and kiss the ground. To embrace the land that gave him succour when he needed help as a little boy" (6 August 2012: 6-7). However, as if wrapping himself up in the Union flag in post-race celebrations was not a sufficient display of his Britishness, every newspaper reported how at the post-race press conference a journalist evoked the 'plastic Brit' epithet, and questioned Farah's British credentials, asking Farah if he would have preferred to run for Somalia. Farah responded indignantly, "Look mate, this is my country. When I put on my Great Britain vest I feel proud-very proud. (Daily Mail, 7 August 2012: 14). Reflecting on Farah's pledge of allegiance and loyalty as a proud, assimilated British Muslim who had passed a modern version of the Tebbit test, ${ }^{15}$ Daily Mail sports journalist Laura Williamson enthusiastically proclaimed Farah an insider and reflected that Farah's success was “.... something inspirational and uplifting that tells us about the power of sport and the make-up of the nation we live in today. Farah is a success story made in Britain: a Londoner who won gold...He's ours, ours, ours." (9 August 2012: 2)

At the beginning of the New Millennium, Yasmin Alibhai-Brown (2001), an eminent British journalist, academic and authority on British immigration, diversity, and multiculturalism had noted the dawn of what she sensed was a new inclusive modern Britain. This perspective underpinned the dominant narratives found in the newspaper coverage of 'Super Saturday.' Sport journalist Jim White argued that the success of the three British winners in the Olympic stadium on 'Super Saturday' "... demonstrated that anyone from any minority can succeed in a country as tolerant as this: Jessica Ennis, Mo Farah, and Greg Rutherford, the mixed race woman, the refugee, and the ginger kid." He reminded his Daily Telegraph readers how former Prime Minister John Major had sought a multicultural "nation at ease with itself" and reporting on the events of 'Super Saturday,' declared "here it is" (6 August 2012: 23). Trevor Kavanagh, The Sun's political editor, enthused about what he perceived to be, at least temporarily, a synergized plural British identity, symbolized by a communal celebration of the success of multinational, multi-ethnic, and multi-racial athletes. Kavanagh thought Twitter captured the 
enthusiastic, celebratory embrace of British diversity during 'Super Saturday' brilliantly: “A Somalian, a mixed race woman and a ginger man walked into a bar. Everyone bought them a drink" (The Sun, 6 August 2012: 10). The Sunday Mail's editorial enthused how 'Super Saturday' “...transformed the spirits of the nation" and emphasized how winning medals may have influenced the narratives when it described how "the bedraggled ugly duckling is now a beautiful swan bedecked with a dazzling array of golden medallions" (5 August 2012: 29). Dominic Sandbrook writing in the Saturday essay section under the headline "Rebirth of Britishness" asked, "What better symbol could there be of a united inclusive country in the post-imperial age? What better advert for British identity; confident and colour blind?" (Daily Mail, 11 August 2012). Michael Deacon, The Daily Telegraph's television critic concluded Mo Farah is an immigrant. Jessica Ennis is mixed race. Most of our gold-winning rowers are women. Clare Balding, the BBC's best and most popular Olympics presenter, is gay. In other words: these Games are a triumph not only for Britain; they're a triumph for modern Britain. It's a privilege to watch them. (6 August 2012: 2)

Brian Reade, a Daily Mirror sports columnist summarized, “...these Games have made us feel more at ease with who we are. A modern, creative, generous, tolerant nation that can still win (August 13, 2012: 3). Undoubtedly Mo Farah and Jessica Ennis's performances on 'Super Saturday' showcased Britain's new multi-cultural identity and the theme of inclusivity resonated in the newspaper narratives because the LOG was the first time that every country sent female athletes, especially those from Islamic nations who broke with age-old traditions to compete. All newspapers reported Lord Coe's ringing endorsement of the gold medal successes of the British women, such as Nicola Adams, a woman of color, who, in women's boxing's Olympic debut, won the gold medal in the women's flyweight division. Coe also noted how the concept of sportsmanship and fair play was invoked by British fans, who supportively acknowledged the barriers women from several Muslim countries broke through just to compete. However, as Burdsey (2016) noted the progressive, inclusive narratives, embracing proud, successful multiethnic, hybrid British athletes during the LOG, stand in stark contrast with the lived 
realities of many in a multicultural Britain that has increasingly been marked by segregation, social exclusion, and economic deprivation. As Rojek (2007) commented, many British Muslims feel a sense of estrangement from British culture, which was compounded by the British government's foreign policy support of the United States invasion of predominantly Muslim Iraq and Afghanistan, which fueled Islamic fundamentalist extremism and the homegrown Muslim terrorists responsible for the $7 / 7$ terrorist bombings on the London Transport system, the day after London won the bid to host the Olympics.

\section{Discussion}

Tomlinson (2014: 248) described "...how the messages of Olympism are interpreted anew according to the interests and priorities of the host city" and this study provides a point of reference for future research examining how forthcoming Olympic host nation's national identity is framed by their press. As Bairner (2005: 92) noted, national representative teams competing in mega sport events are “... one of the easiest and most passionate ways of underlining one's sense of national identity ... in the modern era." As such, hosting 'the greatest show on earth' provided the host nation with a unique opportunity to rework its national image for a global media audience. It also allowed the British journalists to reengineer its national identity to reinforce some traditional values and inject some new inclusive ones. Accordingly, this study has sought to provide a snapshot of how the British viewed themselves through the prism of newspaper narratives as they went about staging and participating in the LOG, when the emotionally charged carnival atmosphere of sporting competition intersected with national identity politics for the mediated consumption of the 'imagined community.'

In contrast to the malign tribalism found in newspaper tropes about the English men's football team competing in World Cups ${ }^{16}$ and the binary 'us versus them' nationalism found in the televised coverage of Team USA in successive Olympics, while in keeping with both the universalism of the Olympic Charter and the tenets of the BOA bid, British newspaper narratives generally positioned Britain 
as welcoming, progressive, inclusive, and cosmopolitan. Given that London is one of the most ethnically diverse cities in Europe (Girginov, 2013), it was fitting that narratives reflected the multi-cultural lineages of several high profile and successful British Olympians, set against the iconic backdrop of the capital's majestic British architectural heritage that incorporated “...familiar landmarks ... in new and wondrous light as Olympic settings," (The Daily Telegraph, 4 August 2012: 21). However, illustrating the inherent tensions between the benign universalism of the Olympic charter and the desire for competitive victory, British newspaper narratives also fixated on how British medal success captivated the nation, in an albeit temporary mood of self-congratulatory euphoria as Team GB won 65 medals and placed third in the medal table, behind only super powers the United States and China. This was an unprecedented British achievement in contemporary Olympiads although this was then surpassed in Rio 2016 when Team GB came second in the medal table.

Although Hall (1973) outlined how readers possess the agency to decode narrative texts in different ways, he noted the influence the media have in promoting 'preferred' ways of reading narratives, and this paper argues that the dominant British newspaper narratives generally reflected the BOA bid themes and framed modern Britain as progressively benign, emphasizing discourses celebrating the success of selective multiethnic, hybrid, loyal British athletes, while largely ignoring the unsuccessful so-called 'plastic Brits,' and, for the defined temporal period of the Games, largely glossing over divisive issues. However, the contentious nature of traditional British national identity politics was reflected in several conservative counter narratives criticizing Boyle's relatively benign opening ceremony, the insular rhetoric about the Welsh and Scottish football (soccer) players on Team GB refusing to sing God Save the Queen before their matches, and the privileged background of many of the British athletes. The 'us versus them' discourse exchanges reported between British politicians, Olympic officials and their French and American peers also illustrated how some traditional, malign British values had not been vanquished. 
The legacies of the LOG will evolve and be debated over coming decades ${ }^{17}$ because as Horne (2007: 86) noted, "legacies" are the "known unknowns" of sports mega-events and it seems "evident" (known) that forecasts are nearly always wrong.' Although several critical narratives expressed doubts about the lasting transformational effect of hosting the Games and skepticism about whether the full impacts and legacies of the LOG outlined in a succession of government reports (see HM Government, 2016) would ever be fully realized, most newspapers captured the sense of self-satisfaction and relief as the Games concluded and demonstrated Britain's ability to deliver successful mega-sporting events, which enabled Lord Coe in his self-congratulatory closing speech to declare, "When our time came, we did it right" (Daily Mirror, 13 August 2012: 6). Although the narratives also revealed the complex, heterogeneous, and contested nature of British national identity, we conclude that in line with Edmunds and Turner's (2001) concepts of benign identity, the cosmopolitan ideals of a fully integrated Olympics and the socially inclusive themes laid out in the BOA bid resonated in the narratives for the 'imagined national community.' Further, the traditionally hierarchical and segregated 'imagined community' of $20^{\text {th }}$ century Britain was re-positioned in the narratives towards a $21^{\text {st }}$ century ideal of an integrated global image through the benign lens of the Olympic spirit. Although there were differences in style, vernacular, and political ideology, generally similar themes and sentiments were found in both broadsheet and popular newspapers. Reflecting the transformational power of sports to inject the 'imagined community' with benevolent patriotism, sports columnist Des Kelly concluded,

We loved the sense of community, the celebration of how wonderful and diverse human beings are. We loved the coming together of people, the understanding that despite colour, creed or politics, we're all essentially the same....For a time London and Britain was beautiful; it was the best it could be-and all because of sport (Daily Mail, 11 August 2012: 93).

Reflecting a triumphant glow, a Daily Telegraph editorial concluded that, albeit temporarily, "The Games might have provided pleasant proof that Britain's claim to the prefix "Great" is not a hollow one" (11 August 2012: 23). However, as Parekh (2000: 13) elucidated, "The search for national identity is an 
unending process, both because a rich and complex society cannot be reduced to a crisp definition and because new circumstances constantly call for new definitions."

We wonder for example whether the devolutionary trends in Scotland and Wales may one day render Great Britain and Team GB obsolete. The 2016 vote for Britain to leave the European Union (Brexit) has caused both Scotland and Northern Ireland to seriously review their positions as part of Great Britain and the United Kingdom. Yet at the end of the summer of 2016 another stellar performance by Team GB in the 2016 Olympic Games has witnessed another mediated outpouring of British pride, however superficially, which once again demonstrated the remarkable power of sport. 
1. In reaction to Britain's loss of power and influence, in the 1990's a "Little Englander" island insular attitude re-asserted itself (Maguire, 2011). The "Little Englander" mentality, which reflected a desire for England to return to a former golden age, was promulgated by then Conservative Prime Minister John Major, in part, as a response to England's perceived 'identity crisis.'

2. The Dunkirk evacuation occurred in 1940, at the beginning of the Second World War. Over 300,000 British troops had been cut off by the advancing German army and were stranded in the northern French port of Dunkirk. They were rescued by a flotilla of nearly 700 military ships and voluntary civilian boats and safely repatriated to Britain. This daring escape captured the imagination of the British public at a time when it seemed that Britain may be invaded. What was actually a defeat seemed almost like a victory when so many men were safely rescued and since then the 'Dunkirk spirit' has become part of British mythology. It is commonly used to describe British people working together to overcome adversity.

3. Porter (2004: 32) noted Britain's waning geo-political influence, signaled in its retreat from Suez in 1956 and loss of the Empire, coincided with its relative economic decline. This meant that those "...born in the post-war era became accustomed to the idea that they belonged to an old country that had seen better days." For decades this message was promulgated for public consumption in the plethora of newspaper narratives of national decline, which served to shape Britishness in the minds of the 'imagined community' (see Nairn, 1977 and Paxman, 1999).

4. When representing their nation in mega sporting events athletes become highly visible personifications of the nation for the 'imagined community' (see Tuck and Maguire, 1999).

5. On 18th June, 1940, at the beginning of the Second World War, Winston Churchill, Britain's Prime Minister, delivered his 'finest hour' speech to galvanize the nation in the immediate aftermath of France surrendering to Germany, which left Britain to stand alone against German military aggression. The often-quoted end of the speech, which has become part of British mythology, reads:

Let us brace ourselves to our duties, and so bear ourselves that, if the British Empire and its Commonwealth last for a thousand years men will say, this was their finest hour.

Paul Gilroy (2005) critically argued that a nostalgia for Britain's 'finest hour' represents a yearning for a return to the by-gone era and values of Anglo-Saxon homogeneity.

6. Eton Dorney, a purpose-built lake in a 400 -acre park, owned by Eton, hosted the Olympic and Paralympic rowing competitions and canoe sprint event. Eton, founded by King Henry VI, in 1440, is a prestigious independent boarding school for boys. Traditionally, Eton has educated boys from privileged backgrounds and infused sport in the academic curriculum to cultivate the values and character of the British governing class. Distinguished alums of Eton, known as Old Etonians, have included generations of British Prime Ministers, statesmen, the aristocracy, and members of the royal family. David Cameron, the British Prime Minister and Boris Johnson, the Mayor of London during the LOG are both old Etonians. 
7. The Home Counties are the counties of England that broadly border London, and as such are known as the London commuter belt because many inhabitants commute to work in the capital and are generally more prosperous than other parts of the United Kingdom.

8. Millfield and Gordonstoun are esteemed co-educational independent boarding schools. Millfield is known for its rigorous academic standards and sporting prowess, having produced many Olympic athletes. Alums are known as Old Millfieldians. Gordonstoun has many notable alumni, including the Duke of Edinburgh and the Prince of Wales.

9. Winston Churchill, Britain's wartime Prime Minister, coopted the $\mathrm{V}$ sign gesture ( $\mathrm{V}$ for Victory) as his hallmark gesture to represent defiance, determination, and victory.

10. The resistance encountered in creating a unified Team GB football (soccer) team illustrated the complexity, contestation, tribalism, and insular nature of British national identity politics. For detailed accounts (see Ewan, 2012; Gibbons, 2014; Harris and Vincent, 2015; MacRury and Poynter, 2010).

11. Generally before international sporting events only the first two verses are sung.

12. Sheffield is a city in South Yorkshire, northern England, with a rich tradition of industrial production in iron, steel, and coal mining in the outlying areas.

13. Journalist Simon Barnes reference to Jessica Ennis being our Jerusalem, evokes William Blake's early nineteenth century poem Jerusalem, which postulates that there may have been a divine visit to England's 'green and pleasant lands' by Jesus, and in doing so, implies a sense of English/British exceptionalism. Blake's poem was set to music in 1916 by Sir Hubert Parry's anthem, Jerusalem, which was played during the LOG opening ceremony, and has been used as an alternative English national anthem to God Save the Queen.

14. Milton Keynes in a city located in Buckinghamshire, in Home Counties England. It was formed in the 1960s, as one of several new towns created in the south-east of England to relieve housing congestion in London.

15. Commenting on the politics of immigrant assimilation and integration, in 1989, Norman Tebbit, a Thatcherite Conservative cabinet minister, noted how many Pakistani and Indian immigrants in Britain supported their ancestral homelands against England in international cricket matches and suggested they lacked loyalty to Britain, and, therefore failed the assimilationist test. However, the Tebbit test overlooks that identities are multilayered and nuanced and does not reflect that it is possible to simultaneously be proud of being British while also feeling a strong sense of pride and nostalgia for one's ancestral homelands.

16. Numerous authors have examined English newspaper coverage of the men's English football (soccer) team competing in the World Cup and European Championships (see Maguire and Poulton, 1999; Vincent and Harris, 2014; Vincent and Hill, 2011; Vincent, et al., 2010).

17. For critical examination of the LOG legacy (see Girginov, 2014b; McGuinness, 2015; Weed, 2013; and Weed, 2014). 


\section{References}

Alibhai-Brown Y (2001) Who do we think we are? Imagining the new Britain. London: Penguin.

Andrews DL and Rick OJC (2014) Celebrity and the London 2012 spectacle. In: Girginov V (ed.) Handbook of the London 2012 Olympic and Paralympic Games. Volume Two: Celebrating the Games. London: Routledge, 195-212.

Anderson B (1983) Imagined Communities: Reflections on the Origin and the Spread of Nationalism. London: New York: Verso.

Aughey A (2007) The Politics of Englishness. Manchester: Manchester University Press.

Bairner A (2005) Sport and the nation in the global era. In: Allison L (ed.) The Global Politics of Sport: The Role of Institutions in Sports. London: Routledge, 87-100.

Bhabha HK (1990) Introduction: Nation and narration. In: Bhabha HK (ed.) Narrating the Nation. London and New York: Routledge, 1-7.

Billig M (1995) Banal Nationalism. London: Sage.

Billings A (2008) Olympic Media: Inside the Biggest Show on Television. London and New York: Routledge.

Billings AC Angelini JR and Wu D (2011) Nationalistic notions of the superpowers: Comparative analyses of the American and Chinese telecasts in the 2008 Beijing Olympiad. Journal of Broadcasting and Electronic Media, 55(2): 251-266.

Bogdanor V (2002) 'Lions, Unicorns and Ostriches ...' The Times Higher Education Supplement, November 8.

Boorstin DJ (1961) The Image: A Guide to Pseudo-events in America. New York: Vintage.

Burdsey D (2016) One guy named Mo: Nation and the London 2012 Olympic Games. Sociology of Sport Journal 33(1): 14-25.

Butterworth ML (2007) The politics of pitch: Claiming and contesting democracy through the Iraqi national soccer team. Communication and Critical/Cultural Studies, 42(2): 184-203.

Chadband I (2012). London 2012 Olympics, Day 8, nothing can ever beat Super Saturday. The Daily Telegraph, 28 December. Available at http://www.telegraph.co.uk/sport/olympics/ 9764832/London-2012-Olympics-Day-8-nothing-can-ever-beat-Super-Saturday.html

Chen CC and Colapinto C (2010) Beijing Olympics between media sport and politics: Perspectives from the Swiss and Italian media. The International Journal of the History of Sport, 27(9-10): 16941716.

Coe S (2012) Running my Life: The Autobiography. London: Hodder and Stoughton.

Cohen R (2000) The incredible vagueness of being British/English. International Affairs 76(3): 575-582. 
Colley L (1992) Britishness and otherness and national identity: An argument. Journal of British Studies 31: 309-329.

Colley L (2007) Does Britishness still matter in the Twenty-First Century-and how much and how well do the politicians care? The Political Quarterly 78: 21-31.

Colley L (2009) Britons: Forging the nation, 1707-1837 ( ${ }^{\text {rd }}$ ed.) New Haven: Yale University Press.

Collins D and Cruikshank A (2013) Preparing Team GB for London 2012. In Girginov V (ed.) Handbook of the London 2012 Olympic and Paralympic Games. Volume One: Making the Games. London: Routledge, 114-129.

Colls R (2011) The lion and the eunuch: National identity and the British genius. The Political Quarterly 82(4): 574-595.

Creswell JW (2003) Research Design: Qualitative, Quantitative and Mixed Methods Approaches ( $2^{\text {nd }}$ ed.) Thousand Oaks: Sage.

Edmunds J and Turner BS (2001) The re-invention of a national identity?: Women and cosmopolitan Englishness. Ethnicities 1(1): 83-108.

Ewen N (2012). Team GB, or no Team GB, that is the question: Olympic football and the post-war crisis of Britishness. Sport in History 32(2): 302-24.

Fox K (2004) Watching the English: The Hidden Rules of English Behaviour. London: Hodder and Stoughton.

Gamble A and Wright T (2009) Introduction: The Britishness question. In: Gamble A and Wright T (eds) Britishness: Perspectives on the Britishness Question. Chichester: West Sussex: Wiley-Blackwell, 1-9.

Gao F (2010) Politics/nationalism affect 2008 Olympics coverage. Newspaper Research Journal 31(4): 77-92.

Gibbons T (2014) Fan debates on Team GB at the London 2012 Olympics and the Alumnia case. In: Gibbons T (ed.) English National Football Identity and Football fan Culture: Who are Ya? Farnhan, Surrey: Ashgate Publishing Company, 87-123.

Gilroy P (2005) Postcolonial Melancholia. New York: Columbia University Press.

Girginov V (2013) Social, political, economic and operational context of the 2012 London Olympic and Paralympic Games: An introduction. In: Girginov V (ed.) Handbook of the London 2012 Olympic and Paralympic Games. Volume One: Making the Games. London: Routledge, 1-13.

Girginov V (2014a) Researching and writing about the London Games: An introduction. In: Girginov V (ed.) Handbook of the London 2012 Olympic and Paralympic Games. Volume Two: Celebrating the Games. London: Routledge, 1-15. 
Girginov V (2014b) London 2012: Beyond everyone's games? In Girginov V (ed.) Handbook of the London 2012 Olympic and Paralympic Games. Volume Two: Celebrating the Games. London: Routledge, 297-302.

Guibernau M (2007) The Identity of Nations. Cambridge: Polity.

Hall S (1973) Encoding and decoding in media discourse, Stencilled paper 7, Centre for Contemporary Cultural Studies, University of Birmingham.

Hall S (2000) Modernity: An introduction to modern societies. In: Hall S, Held D, Hubert D and Thompson K (eds) The Question of Cultural Identity. Oxford: Blackwell Publishers, 596-632.

Harris J and Vincent J (2015) Narratives of Britishness and Team GB in the national newspaper of Wales. International Journal of Sport Communication, 8: 1-17.

Harvie C (2000) The moment of nationalism, 1939-1970. Political Quarterly, 71: 328-340.

Hayton R, English R and Kenny M (2009) Englishness in contemporary British politics. In: Gamble A and Wright T (eds) Britishness: Perspectives on the British Question. Chichester, West Sussex: WileyBlackwell, 122-135.

Hitchins P (2008) The Abolition of Britain. London: Quartet.

HM Government and Mayor of London (2016). Inspired by 2012: The legacy from the Olympic and Paralympic Games. Fourth annual report-summer 2016. Whitehall, London: Cabinet Office. Available at: https://www.gov.uk/government/uploads/system/uploads/ attachment_data/file/544197/1776-E_Legacy_Report_2016_ACCESSIBLE.pdf

Hobsbawm EJ (1990) Nations and Nationalism since 1780. Cambridge: Cambridge University Press.

Horne J (2007) The four "known" of sports mega-events. Leisure Studies 26(1): 81-96.

Ingham AG and McDonald MG (2003) Sport and community/Communitas. In: Wilcox RC, Andrews DL, Pitter R and Irwin RL (eds) Sporting Dystopias: The Making and Meanings of Urban Sport Cultures. Albany, NY: State University of New York Press, 17-34.

Jenkins SPR (2005) Sport Science Handbook; The Essential Guide to Kinesiology, Sport and Exercise Science (Volume 2, I-Z). Brentwood, Essex: Multi-science Publishing.

Jowell T (2007) Speech at the Legacy Lives conference, 30 January. Available at: http://webarchive.nationalarchives.gov.uk/20121204113822/http://www.culture.gov.uk/refere nce_library/minister_speeches/2078.aspx

Knight G MacNeill M and Donnelly P (2005) The disappointment games. Narratives of Olympic failure in Canada and New Zealand. International Review for the Sociology of Sport, 40: 25-51.

Kureishi H (1989) London and Karachi. In: Samuel R (ed.) Patriotism: The Making and Unmaking of British National Identity, Vol. 2 Minorities and Outsiders. London: Routledge, 270-287. 
Larson JF and Rivenburg NK (1991). A comparative analysis of Australian, US, and British telecasts of the Soul Olympic opening ceremony. Journal of Broadcasting and Electronic Media, 35: 75-94.

Leonard M (1997) Britain TM: Renewing our Identity. London: Demos.

Llewellyn M (2012) Rule Britannia: Nationalism, Identity and Modern Olympic Games. London: Routledge.

MacRury I and Poynter G (2010) 'Team GB' and London 2012: The paradox of national and global identities. The International Journal of the History of Sport 27(16-18): 2958-2975.

Magnay J (2010) London 2012 Olympics: The broadcaster. The Telegraph, 27 July. Available at: http://www.telegraph.co.uk/sport/olympics/7907480/London-2012-Olympics-thebroadcaster.html

Maguire J (2011) Globalization, sport and national identities. Sport in Society 14(7/8): 978-993.

Maguire J and Poulton EK (1999) European identity politics in Euro 96: Invented traditions and national habitus codes. International Review for the Sociology of Sport 34(1): 17-29.

Malcolm D (2009) Malign or benign? English national identities and cricket. Sport in Society 12(4/4): 613-628.

Mandela N (2000) Speech by Nelson Mandela at the Inaugural Laureus Lifetime Achievement Award, Monaco. Available at: http://db.nelsonmandela.org/speeches/ pub_view.asp?pg=item\&/temID=NMS1148

McGuinness M (2015) A critical examination of the London 2012 legacy. In: Dixon K and Gibbons T (eds) The Impact of the 2012 Olympic and Paralympic Games. Basingstoke, Hampshire: Palgrave McMillan, 72-93.

Marr A (2007) A History of Modern Britain. London: Macmillan Publishers.

Miller D (1995) On Nationality. Oxford: Oxford University Press.

Nairn T (1977) Faces of Nationalism: Janus Revisited. London: Verso.

Nairn T (2000) After Britain: New Labour and the Return of Scotland. London: Granta.

Parekh B (2000) 'Defining British national identity.' Political Quarterly 71: 4-14.

Paxman J (1999) The English: A Portrait of a People. London: Penguin.

Polley M (1998) Moving the goalposts: A history of sport and society since 1945. London: Routledge.

Porter D (2004) 'Your boys took one hell of a beating!': English football and British decline, c. 1950-80. In: Smith A and Porter D (eds) Sport and National Identity in the Post-war World. Routledge: Abingdon, Oxon: Routledge, 31-51. 
Poulton E and Maguire J (2012) 'Plastic' or 'fantastic' Brits? Identity politics and English media representations of 'Team GB' during London 2012. JOMEC Journal 1(2): 1-30.

Raphael A (ed) (2013) Danny Boyle: Creating Wonder. In Conversation with Amy Raphael. London: Faber.

Rojek C (2007) Brit-myth: Who do the British Think They Are? London: Reaktion.

Rojek C (2001) Celebrity. London: Reaktion.

Rowe D McKay J and Miller T (1998) Come together: Sport, nationalism, and the media image. In L.A. Wenner (Ed.) MediaSport. London: Routledge, 119-133.

Smith AD (1998) Nationalism and Modernism. London: Routledge.

Strauss A and Corbin J (1999) Basics of Qualitative Research: Grounded Theory Procedures and Technique $\left(2^{\text {nd }}\right.$ ed.) Newbury Park, CA: Sage.

Tomlinson A (2014) Seizing the Olympic platform: 6.6 million and counting. In Girginov V (ed.) Handbook of the London 2012 Olympic and Paralympic Games. Volume One: Making the Games. London: Routledge, 238-251.

Tuck J and Maguire (1999). Making sense of global patriot games: Rugby players' perceptions of national identity politics. Football Studies 2(1): 26-54.

Uberoi V and Modood T (2013) Inclusive Britishness: A multicultural advance. Political Studies, 61(1): 23-41.

Vincent J and Crossman J (2015). "Our Game Our Gold:" Canadian national identity in newspaper narratives about the men's ice hockey team at the 2010 Winter Olympic Games. Journal of Sport Behavior, 38(1): 97-117.

Vincent J and Harris J (2014) "They think it's all Dover!" Popular newspaper narratives and images about the English football team and (re)presentations of national identity during Euro 2012. Soccer and Society, 15(2): 222-240.

Vincent J and Hill JS (2011) Flying the Flag for the En-ger-land: The Sun's (re)construction of English Identity during the 2010 World Cup. The Journal of Sport and Tourism, 16(3): 187-209.

Vincent J and Kian E (2014) Sport, new media, and national identity. In Billings AC and Hardin M (eds) The Routledge Handbook of Sport and New Media. New York: Routledge, 299-310.

Vincent J, Kian EM, Pedersen PM, Kuntz A and Hill JS (2010) England expects: English newspapers' narratives about the English soccer team in the 2006 World Cup. International Review for the Sociology of Sport 45(2): 199-223.

Ward P (2004) Britishness since 1870. London: Routledge. 
Weed M (2013) London 2012 legacy strategy: Ambitions, promises and implementation plans. In: Girginov V (ed.) Handbook of the London 2012 Olympic and Paralympic Games. Volume One: Making the Games. London: Routledge, 87-98.

Weed M (2014) London 2012 legacy strategy: Did it deliver? In: Girginov V (ed.) Handbook of the London 2012 Olympic and Paralympic Games. Volume Two: Celebrating the Games. London: Routledge, 281-294.

Weight R (2002) Patriots: National Identity in Britain 1940-2000. Basingstoke: Macmillan.

Whannel G (2002) Media sport stars, masculinities and moralities. London: Routledge. 